\title{
Branding Halal: A Delicate Balance
}

\author{
Marco Tieman*
}

Traditionally, halal status has been assumed for all non-pork food products and non-alcoholic beverages available in Muslim countries. Halal certification bodies changed this precept, however, by issuing halal certificates for processed food, beverages, and non-food products based on an assessment of ingredients used and production processes. This allowed brand owners to place a halal logo on their products or outlets. The result has been that halal-certified products are available in the market place but, at the same time, there is a greater diversity of halal logos due to the presence of imported products sold by retailers.

Today, it is not easy for Muslim consumers to understand the difference between the various halal logos, to determine the amount of trust they should place in a specific halal logo, and, of course, how Islamic schools of thought, fatwas (religious rulings) or local customs impact upon the halal integrity of a product. Some Muslim (majority) countries, like Indonesia, have taken regulatory action forbidding consumer products to carry any halal logo other than their country's own. Most Muslim countries, however, have not taken this action. As a result, in supermarkets today you not only find a greater diversity of halal logos on consumer products, but even within a single corporate brand.

Labelling a product or outlet as halal does not just mean permissible; it also says that the product and its processes are religiously pure. The goal of branding a product halal is to communicate to the consumer that that product has been verified halal by an independent certification body. There are three possible ways to communicate this: co-branding, ingredient branding, or halal-coding.

Seeking opportunities in the fast-growing halal market, companies are increasingly using halal as co-branding when marketing their products to Muslims. Halal co-branding is practiced when 'halal', 'Islamic' or 'shariah' (Islamic law) are jointly used with a corporate brand on a product or service. Shariah compliance, symbolised by the halal logo, is foregrounded during the branding exercise with the goal of harvesting brand synergy advantages. Leading academic literature on halal branding defines this category as a 'halal brand', where a branded product or outlet is clearly positioned, signalled and communicated to be aligned with the values, norms, and ideals of the Muslim faith. Examples of companies that do this in Malaysia are KFC and McDonalds; in Indonesia the cosmetics company Wardah does the same. 
Halal ingredient branding considers the halal logo to be part of the product label, equal in value to tayyib (wholesome) certificates in food quality and safety. Halal ingredient branding emphasises the halal compliance of the product for the Muslim consumer. The halal logo is present, but on (or next to) the product label (instead of at the front of the product packaging) or, in the case of an outlet, mentioned somewhere on the menu and/or a halal certificate displayed at the outlet. A halal logo and stat us are not promoted explicitly in commercials and advertising. Food and cosmetics manufacturers, as well as restaurants, use this approach in Thailand.

A third option, not yet practiced, is halal-coding. This approach is currently used for Kosher labelling. Kosher uses the symbol ' $\mathrm{K}$ ' with optional additional words - 'Pareve' (neutral), 'D' or 'Dairy' (products containing dairy), 'DE' (dairy equipment), or ' $\mathrm{P}$ ' (Passover dietary laws) - to signal when something complies with Jewish dietary laws. Within a Muslim context, instead of showing a halal logo, a halal code could be used on labels or food menus - the letter ' $\mathrm{H}$ ', for example, followed by additional symbols indicating a halal authority (e.g. ' $\mathrm{H}$ Jakim'), a slaughtering process (e.g. ' $\mathrm{H} 01$ ' for hand slaughtered, no stunning), or 'H Vegan' for vegan halal products.

Next to traditional halal certified industries like food, cosmetics and pharmaceuticals, other consumer products and industrial brand owners want to carry halal logos, including for fashion, cat food, refrigerators, paint, and much more. Although it is logical that halal compliance should be an important market qualifier for doing business in Muslim markets, being essential for protecting Muslim consumers as well as the corporate halal reputation of brand owners, there are important philosophical questions to be answered. Are there possible risks in over-branding halal? Is there not a danger that the actual needs of the consumer are overlooked, creating resentment towards a brand, or that consumers are even scared away? Are these companies, instead of creating a stronger corporate halal authenticity, not destroying halal values instead?

\section{Branding halal in Muslim (Majority) and non-Muslim Countries}

When are we over-branding halal? What are the risks of over-branding halal in Muslim (majority) and non-Muslim countries?

Over-branding in Muslim countries is when:

- Halal co-branding is used for products that are not tayyib (for example, products that are nutritionally deficient, harmful to the body, use child labour, or pollute our waterways). Once discovered or exposed, brand owners could see their products rejected and see the sales drop. 
- Halal co-branding is used for products and services for which halal certification is not essential to protect the Muslim way of life. This might create doubt about the intention of the brand owners and scare consumers away. The same could be true when the halal logo is branded extensively on a category of products or services new to halal certification.

- Halal co-branding is used when halal compliance is not considered beyond the first tier of the supply chain - that is, between only the first tier supplier and the first tier customer (instead of the entire end-to-end supply chain). This could expose the halal integrity of a product. Halal issues in the supply chain for brands that originate from non-Muslim countries (also known as inbound Islamic brands) could have major consequences for sales and corporate halal reputation.

Halal co-branding is more effective than halal ingredient branding in Muslim (majority) countries for: food, nutrition, beverages, and cosmetics that go into the mouth; that are tayyib and where brand owners take a halal supply chain approach.

When halal is over-branded in non-Muslim countries, there could be negative reactions from non-Muslims and even halal boycotts, as recently seen in Europe. Over-branding in non-Muslim countries could damage both the corporate reputation of halal-certified brand owners and the general perception of halal among non-Muslims. It could therefore create hardship for Muslims who desire access to halal products. Research shows that negative reactions are predominantly happening in non-Muslim countries where there is no halal regulation.

Halal-coding is more effective than halal ingredient branding in nonMuslim countries without a halal law (through a halal act or labelling law) and government accredited halal certification bodies.

\section{Conclusions and Recommendations}

Halal certification is essential when operating in Muslim markets. However, halal branding requires a very delicate balance when promoting halal stat us to consumers.

Halal co-branding is only recommended in Muslim (majority) countries for food, nutrition, beverages, as well as cosmetics that go into the mouth (including toothpaste, mouthwash). However, halal co-branding exposes the brand owner if products are not found to be tayyib or are demonstrated to have non-compliant halal supply chains. This branding tool should therefore be very carefully applied. 
Halal ingredient branding is the norm for branding halal products in Muslim (majority) countries. Halal ingredient branding is also recommended for halal products in non-Muslim countries where halal is protected by law (through a halal act or labelling law) and halal certification bodies are accredited by the government. Example countries include Singapore and Thailand.

Halal-coding is recommended for non-Muslim countries without halal laws and accredited halal certification bodies. In these markets, halal ingredient branding is not considered attractive for the mainstream market and may even result in halal boycotts. But, instead of not sharing the halal stat us of a product, it would benefit Muslim consumers to have a halal code on the ingredient label. Markets that would certainly gain from this communication method are China, Russia, Europe, Australia, and the USA.

The Muslim consumer should be able to blindly trust products labelled halal. It is essential for governments in both Muslim and non-Muslim countries to protect halal through both regulation and enforcement. Government accreditation of halal certification bodies is necessary to control the wild growth of questionable halal certification bodies, inflation of halal certificates, and protection of halal as a mark of excellence (ihsan).

Conservatism is needed when introducing new products and services that could be halal certified. I would like to argue that decisions on what products and services can be halal certified should be agreed among leading halal certification bodies or, even better, at the Organisation of Islamic Cooperation (OIC). This control mechanism would aid and protect international halal trade. By contrast, creative halal certification initiatives by individual halal certification bodies could be confusing for consumers and the industry, damaging the reputation of halal and creating (unintended) trade barriers.

The introduction of a universal halal code agreed upon by the OIC, and similar to that for Kosher, is of paramount importance for accessing halal products in non-Muslim countries, where halal logos are not always attractive for brand owners. Currently, many halal-certified products on consumer shelves in non-Muslim countries do not show a halal logo; as a result, it becomes very difficult for Muslims to ascertain the halal status of these products. This is a missed opportunity to move halal mainstream! By contrast, the introduction of a halal code on product labels will reduce hardship for Muslims living in (and visiting) non-Muslim countries when shopping for their daily halal needs. It will also assist brand owners who manufacture in or export to non-Muslim countries.

Further research is needed on halal branding, in particular to test the hypotheses formulated through industry and consumer surveys in both Muslim and non-Muslim countries. 


\section{Notes}

* Marco Tieman is Professor at the ELM Graduate School, Help University, Malaysia. He conducts research on halal supply chain management and halal risk and reputation management. He obtained his Master's degree in industrial engineering and management science [logistics] with the University of Twente (the Netherlands) in 1997 and his PhD in business management [halal supply chain management] with Universiti Teknologi MARA (Malaysia) in 2013. He is also the CEO of LBB International, a supply chain strategy consultancy and research firm with a specialisation in purchasing, production, and supply chain management. He chaired the development of the International Halal Logistics Standard (IHIAS, 0100:2010) under ICCI-IHI Alliance between 2008 and 2010. Marco Tieman can be contacted at: marco.tieman@help.edu.my. 